\title{
PERAN SISTEM SOSIAL DALAM DIFUSI PROGRAM DESA WISATA PUJON KIDUL KABUPATEN MALANG
}

\author{
Jay Henry Kusuma \\ STID Al-Hadid, Surabaya \\ jayhenrykusuma@gmail.com
}

\begin{abstract}
Abstrak: Studi dilatarbelakangi oleh berbagai realitas kesuksesan program desa wisata Pujon Kidul, seperti banyak diminati wisatawan, mendapatkan penghargaan tingkat nasional hingga internasional, dan keuntungan ekonomi yang besar. Di sisi lain mengkaji peran sistem sosial dalam proses difusi inovasi memiliki nilai penting agar masyarakat yang hendak dikenalkan inovasi mau menerima dan berpartisipasi dalam program. Metodologi studi ini termasuk riset kualitatif dengan menggunakan dokumentasi dalam penggalian data. Uji keabsahannya menggunakan triangulasi data. Teori yang digunakan adalah komponen sistem sosial Everet M. Rogers. Tujuan studi adalah mendeskripsikan peran komponen sistem sosial dalam proses difusi inovasi program desa wisata Pujon Kidul. Hasil studinya yaitu: (1) karang taruna berperan sebagai anggota sistem yang menerima inovasi awal dan menjadi percontohan; (2) Udi Hartoko sebagai agen pembaharu sekaligus tokoh masyarakat secara aktif melakukan usaha pengenalan, persuasi, hingga mempertahankan keputusan penerimaan inovasi; (3) Peran ganda ini menyebabkan dirinya mudah dipercaya oleh masyarakat; (4) Musyawarah yang memudahkan proses pengenalan dan persuasi; (5) norma sistem gotong royong memudahkan proses percontohan dalam pemberdayaan; (6) Kesamaan asal usul dan visi membentuk hubungan saling percaya antara masyarakat dengan Udi Hartoko. (7) Ditemukan pula bahwa pendidikan rendah dan paradigma tertutup dengan perubahan memperlambat proses terdifusinya inovasi. (8) Ditemukan keunikan agen pembaharu yang merangkap menjadi tokoh masyarakat.
\end{abstract}

Kata kunci: komponen sistem sosial, program desa wista Pujon Kidul, difusi inovasi

Role of Social System In Diffusing Pujon Kidul - Malang Regency's Tourism Village Program. Abstract : The study is grounded by various successes of Pujon Kidul tourism village program, namely having great demand of tourists, national to international awards, and large economic benefits. Moreover, examining role of social system in innovation diffusion process has an important value so that the community want to accept and participate in the program. It applies qualitative methodology by using documentation as data collecting. Its validity uses data triangulation. It applies Everest M. Rogers' social system component theory. It aims to decribe role of social system components in innovation diffusion process of this program. It indicates: (1) Karang Taruna acts as a system member accepting initial innovation and becoming a model; (2) Udi Hartoko, acting as a reformer and community figure, actively pursues recognition, persuasion, and defending the innovation acceptance; (3) this dual role makes him trustworthy; (4) discussion eases recognition and persuasion; (5) mutual cooperation system eases modelling process in community empowerment; (6) origin and vision similarities form a mutual trust between the community and Udi Hartoko; (7) low education and a closed change 
paradigm decelerate innovation diffusion process; (8) it is found the uniqueness of a reformer also acting as community figure.

Key words : social system components, the tourism village program of Pujon Kidul, innovation diffusion

\section{Pendahuluan}

Kegiatan pemberdayaan masyarakat pedesaan bisa menjadi solusi yang efektif untuk menyelesaikan masalah kesejahteraan. Alasannya solusi yang diberikan tidak hanya pemberian bantuan langsung tunai atau bantuan sembako per bulan. Sebaliknya pemberdayaan menawarkan solusi yang bersifat jangka panjang dengan karakter khasnya adalah mengajak masyarakat untuk aktif berpartisipasi mengubah kondisi kesejahteraan mereka dengan tujuan akhirnya adalah terbentuk masyarakat yang mandiri. $^{1}$

Islam pun memandang baik usaha manusia untuk mengubah nasibnya, seperti yang tertulis pada surah Ar-Ra'd:11. Secara prinsip ayat ini menjelaskan bahwa manusia harus berusaha mandiri apabila ingin mengubah kondisinya menjadi lebih baik lagi. ${ }^{2}$ Dalam hal ini, pemberdayaan adalah salah satu usaha manusia agar menjadi insan yang lebih berdaya khususnya secara ekonomi.

Mendifusikan inovasi program pemberdayaan masyarakat bisa menjadi langkah awal terjadinya perubahan sosial ke arah pembangunan bagi masyarakat pedesaan. Menurut Rogers, difusi inovasi adalah usaha agar suatu inovasi bisa

\footnotetext{
1 Departemen Agama RI, Al-Qur'an Tajwid dan Terjemah, (Jakarta: Dharma Art. 2015), 250.

2 Moh. Rifai dan Roshin Abdulghoni, Al Quran Dan Terjemahannya (Semarang: Wicaksana, 1991), 508.
}

diterima oleh masyarakat. Terdapat komponen sistem sosial yang harus dipertimbangkan dalam proses tersebut. $\mathrm{Di}$ antaranya adalah variabel anggota sistem sebagai penerima manfaat, agen pembaharu, tokoh masyarakat, saluran komunikasi, norma sistem, dan prinsip homophily-heterophily. ${ }^{3}$ Masyarakat adalah objek dari proses difusi inovasi dan di dalam masyarakat terdapat enam komponen sistem sosial. Sehingga mempertimbangkan peran dari enam komponen sistem sosial tersebut akan mendukung penerimaan masyarakat terhadap inovasi. Kemudian inovasi akan menstimulus sebuah perubahan masyarakat ke arah pembangunan. ${ }^{4}$

Penting untuk memahami peran komponen sistem sosial dalam proses difusi inovasi, karena tidak sedikit kegiatan pemberdayaan yang tertolak atau gagal akibat tidak mempertimbangkan aspek tersebut. Beberapa kasusnya adalah pertama, Nelida dalam menyebarkan inovasi program hidup sehat dengan membiasakan minum air matang yang terjadi di desa Los Malinos, Peru. Fakta bahwa Nelida gagal menyebarkan inovasi adalah dua tahun intensif menyebarkan inovasi ini, namun hanya lima persen masyarakat yang menerima. Penyebab kegagalan ini adalah ia tidak mempertimbangkan komponen sistem

\footnotetext{
3 Everett M. Rogers, Diffusion of Innovation Fifth Edition, (New York: Free Press, 2003), 40-41.

${ }^{4}$ Ibid., 59.
} 
sosial dalam proses difusi inovasi, semisal salah dalam menentukan adopter pertamanya, tidak memaksimalkan peran tokoh masyarakat, cenderung menerapkan prinsip heterophily, dan dirinya tidak memaksimalkan berbagai perannya sebagai seorang agen pembaharu. Alhasil, proses difusi inovasi menjadi lambat untuk terserap ke masyarakat. ${ }^{5}$

Kedua, program budidaya lele pada Desa Kucur, Kecamatan Dau, Kabupaten Malang. Disebutkan bahwa terdapat realitas tidak memaksimalkan proses difusi inovasi sehingga masyarakat tidak memahami manfaat inovasi dengan baik hingga akhirnya mereka memutuskan untuk berhenti berpartisipasi. ${ }^{6}$ Ketiga, kasus program e-government dalam pelayanan publik di Kabupaten gresik. Disebutkan bahwa terdapat realitas penerapan inovasi layanan pembayaran pajak kendaraan bermotor secara online yang kurang optimal dalam partisipasi masyarakatnya. Dianalisis penyebabnya adalah masyarakat belum memahami manfaat dari penerapan sistem ini, mereka masih meragukannya, sehingga enggan beralih ke sistem pembayaran online yang sebenarnya lebih efisien. ${ }^{7}$

Dua fakta tersebut adalah realitas difusi yang mengomunikasikan inovasi program budidaya lele dan program layanan e-samsat yang terjadi di Indonesia. Dianalisis

\footnotetext{
${ }^{5}$ Figueroa M.E., \& Kincaid D.L. (2010). Social, Cultural and Behavioral Correlates of Household Water Treatment and Storage. Center Publication HCI 2010-1: Health Communication Insights, Baltimore: Johns Hopkins Bloomberg School of Public Health, Center for Communication Programs, 2010, http://ccp.jhu.edu/documents/Household\%20Water \%20Treatment\%20and\%20Storage\%202010.pdf. (diakses tanggal 29 Februari 2021)

6 Muhammad Luqman Basri, "Kegagalan Program Pemberdayaan Masyarakat Ditinjau Dari Proses Inovasi
}

penyebab kurang optimalnya partisipasi masyarakat adalah akibat masyarakat tidak memahami manfaat dari program tersebut. Ditunjukkan dengan kedua realitas difusi inovasi tersebut sama-sama terdapat realitas masyarakat yang tidak paham apa manfaat program. Masyarakat malah beranggapan sebaliknya, yaitu tidak memahami hingga meragukannya.

Hal ini bisa terselesaikan dengan cara mempertimbangkan peran komponen sistem sosial dalam proses difusi inovasinya, semisal peran agen pembaharu dan tokoh masyarakat yang bisa menjelaskan manfaat program serta disesuaikan dengan karakter norma sistem dan saluran komunikasi yang efektif di masyarakat. Sehingga inovasi bisa terpahami dan potensinya bisa diterima oleh masyarakat. Hal ini sejalan dengan pernyataan Rogers bahwa proses difusi yang mempertimbangkan komponen sistem sosial akan menghasilkan perubahan sosial berupa penerimaan inovasi oleh masyarakat akibat masyarakat memahami inovasi dengan baik khususnya manfaat dari inovasi. $^{8}$

Tiga realitas penolakan proses difusi inovasi tersebut bisa menjadi wujud dari nilai penting mempelajari teori komponen sistem sosial. Karena terdifusinya suatu inovasi adalah langkah awal terjadinya perubahan sosial dan hal ini bisa dilakukan dengan

(Studi Kasus Pada Program Budidaya Lele Desa Kucur Kecamatan Dau Kabupaten Malang)," (Disertasi Program Pascasarjana Universitas Negeri Malang, 2015), xiii.

7 Nur Hidayati, "E-Government Dalam Pelayanan Pubik (Studi Kasus Tentang Faktor-Faktor Penghambat Inovasi Layanan E-Samsat Jatim di Kabupaten Gresik)," (Skripsi Program Studi Ilmu Administrasi Negara Universitas Airlangga, 2016), vii.

${ }^{8}$ Rogers, Diffusion of Innovation Fifth Edition, 66-67. 
mempertimbangkan peran komponen sistem sosial. 9 Maka penting untuk memahami peran komponen sistem sosial. Sehingga menjadikan aktor pemberdaya memiliki pemahaman yang baik tentang peran komponen sistem sosial.

Berbicara tentang inovasi pemberdayaan masyarakat desa, salah satu inovasi yang cukup efektif untuk kegiatan pemberdayaan desa adalah program desa wisata. Program desa wisata adalah kegiatan pemberdayaan dengan cara memaksimalkan berbagai potensi desa semisal potensi alam, budaya, sosial, ekonomi, hingga potensi manusia. Berbagai potensi tersebut akan disuguhkan kepada wisatawan dengan tema kegiatan pariwisata, semisal sebuah atraksi, pertunjukan, atau aktivitas edukasi. ${ }^{10}$ Alasan program desa wisata bisa efektif sebagai alternatif program pemberdayaan adalah data BPS yang mencatat bahwa lebih dari 1.734 desa wisata, mampu sejahtera akibat pengadaan program ini. Hal ini terjadi karena program ini tidak banyak membutuhkan pembangunan infrastruktur besar dalam pengadaannya. Cukup dengan memaksimakan potensi desa, namun potensi keuntungannya bisa mencapai miliaran rupiah. ${ }^{11}$

\footnotetext{
9 lbid., 40-41.

10 Zweni Pramono, Membangun Desa Wisata Untuk Meningkatkan Ekonomi Kerakyatan (Yogyakarta: Rubrik, 2019), 5.

11 Ibid., 19-20.

12 Admin, "Sistem Informasi Elektronik," SIE Pujon Kidul, https://sie.pujonkidul.desa.id/penduduk.php (diakses 7 juni 2020).

13 Raisha Hastiti, "Keterlibatan Karang Taruna Dalam Pemberdayaan Masyarakat Desa (Studi Di Desa Pujon Kidul Kabupaten Malang Melalui Wisata Cafe Sawah)," (Skripsi Program Studi Sosiologi Universitas Muhammadiyah Malang, 2018), 49.

${ }^{14}$ Wildan Arif Hidayatullah "Pemberdayaan Ekonomi Masyarakat Desa Dalam Memenuhi Aspek Maqashid Syariah Melalui Pendekatan Asset Based Community
}

Salah satu desa yang memiliki program desa wisata menarik adalah desa wisata Pujon Kidul yang ada di Kabupaten Malang. Berikut adalah kemenarikannya. Pertama, pemberdayaan yang dilakukan adalah kegiatan memberdayakan masyarakat Islam. Hal ini ditandai dengan mayoritas masyarakatnya yang beragama Islam. 99,91\% penduduknya beragam Islam. ${ }^{12} \mathrm{Hal}$ ini juga diperkuat dengan fasilitas ibadahnya yang hanya ada musala dan masjid saja. ${ }^{13}$ Pemberdayaan yang dilakukan juga berasaskan pada prinsip maqāshid asysyarīah, yaitu berbagai tujuan dalam syariah untuk mendapatkan kebaikan di dunia hingga akhirat. Hidayatullah menyebutkan penerapan program desa wisata Pujon Kidul menerapkan prinsip menjaga agama (hifdz ad-din), menjaga jiwa (hifdz nafs), menjaga akal (hifdz 'aql), menjaga keturunan (hifdz an-nasl), dan menjaga harta (hifdz maal). ${ }^{14}$

Kemenarikan lainnya adalah pengadaan program desa wisata Pujon Kidul banyak mendulang kesuksesan. Berikut adalah berbagai kesuksesannya. Tahun 2017, desa wisata Pujon Kidul dinobatkan sebagai desa wisata terbaik nasional pada kategori agro. ${ }^{15}$ Pada tahun itu, Pokdarwis Capung Alas, juga dinobatkan sebagai Pokdarwis Mandiri tingkat nasional. ${ }^{16}$ Kemenarikan terakhir

Development (Studi Pada Desa Wisata Pujon Kidul Kabupaten Malang Jawa Timur)," (Tesis Program Studi Magister Ekonomi Syariah, Universitas Islam Negeri Maulana Malik Ibrahim, 2019), 127-131.

${ }^{15}$ Admin,"Pujon Kidul Terima Award Sebagai Desa Wisata Agro Terbaik dari Kemendesa," Jawa Pos, 13 Mei 2017, https://www.jawapos.com/wisata-dankuliner/travelling/13/05/2017/pujon-kidul-terimaaward-sebagai-desa-wisata-agro-terbaik-darikemendesa. (Diakses tanggal 28 September 2020) 16 Imam syafii, "kelompok sadar wisata capun alas kabupaten malang raih penghargaan dari menteri pariwisata," jatim times, 28 september 2017, https://jatimtimes.com/baca/159230/20170928/2044 03/kelompok-sadar-wisata-capung-alas-kabupaten- 
adalah pada tahun 2019, Udi diundang pada momen Annual International Forum an Economic Development and Public Police (AIFED) karena dianggap berhasil melakukan kegiatan pemberdayaan. ${ }^{17}$

Kesuksesan kedua adalah program ini mendapatkan keuntungan ekonomi yang besar. Walaupun modal awal pengadaanya di tahun 2014 hanya sekitar enam puluh jutaan, namun dalam rentang dua tahun saja, desa ini sudah balik modal, bahkan untung hingga berkali-kali lipat setelahnya. Tahun 2016 pendapatan desa menjadi 40 juta, 2017 menjadi 162 juta, 2018 menjadi 1,8 milliar, 18 dan pada tahun 2019 keuntungannya adalah lebih dari 1,4 milliar. ${ }^{19}$

Kesuksesan ketiga adalah program ini banyak diminati oleh wisatawan. Berdasarkan data penjualan tiket selama bulan Oktober 2017 hingga April 2018, ratarata pengunjung selama periode tersebut adalah 30.000 pengunjung tiap bulannya. Pengunjung paling banyak ada pada Desember yaitu sebanyak 50.609 pengunjung. ${ }^{20}$

Dalam hal ini, ditemukan indikasi adanya pengoptimalan komponen sistem sosial

malang-raih-penghargaan-dari-menteri-pariwisata. (Diakses pada tanggal 28 September 2020)

17 Admin, "Sistem Informasi Elektronik," SIE Pujon Kidul,

https://www.sie.pujonkidul.desa.id/baca_berita.php? judul=Pembicara\%20di\%20Annual\%20International\% 20Forum\%20an\%20Economic\%20Develobment\%20an g\%20Public\%20police\%20(AIFED). (diakses tanggal 28 September 2020)

18 Intan Margaretha Triaryanti, "Collaborative Governance Dalam Pengelolaan Bumdes Di Desa Wisata Pujon Kidul, Kecamatan Pujon, Kabupaten Malang," (Skripsi Program Studi Ilmu Administrasi Negara, Universitas Airlangga, 2019). 13-14. dalam proses difusi inovasi program desa wisata Pujon Kidul. Indikasi tersebut menjadi dasar bahwa program desa wisata pujon kidul bisa menjadi objek dalam artikel ini. Berikut adalah berbagai indikasinya.

Pertama, dalam suatu wawancara antara Udi dengan Andy F. Noya pada acara Kick Andy. Disebutkan bahwa pada tahun 2005, Udi Hartoko menyebarkan program desa wisata Pujon Kidul ini pertama kalinya kepada kelompok pemuda karang taruna. ${ }^{21}$ Kedua, setelah ia menjabat sebagai kepala desa, ia mulai melakukan berbagai peran sebagai aktor pemberdaya, seperti menunjukkan bahwa Desa Pujon Kidul memiliki banyak potensi seperti potensi keindahan alam, budaya desa, dan ekonomi warga yang bisa dimanfaatkan. ${ }^{22}$ Ketiga, dalam menyampaikan inovasi ini, Udi Hartoko menggunakan saluran komunikasi musyawarah. ${ }^{23}$ Proses difusi yang dilakukan oleh Udi Hartoko adalah sebuah proses panjang. Namun pada akhirnya masyarakat pun menerima inovasi dan percaya dengan inovasi ini. Penerimaan masyarakat ditunjukan dengan adanya partisipasi masyarakat dalam wisata edukasi peternakan, pertanian, dan edukasi UMKM.

\footnotetext{
19 Admin, "Sistem Informasi Elektronik," SIE Pujon Kidul, https://sie.pujonkidul.desa.id/bumdes_last.php (diakses 27 Desember 2020).

20 Hastiti, "Keterlibatan Karang Taruna Dalam Pemberdayaan Masyarakat Desa," 88.

${ }^{21}$ Perjuangann Udi Hartoko Membangun Desa Wisata Pujon Kidul, 00:58-01-15, Video Artikel Internet, diunggah oleh "Medcom", https://www.medcom.id/embed/MkMnRXvK. (diakes 7 Juni, 2020)

22 Hastiti, "Keterlibatan Karang Taruna Dalam Pemberdayaan Masyarakat Desa," 127-128.

23 Citra Tirtaningtyas Damayanti, "Peran Bumdes Dalam Pengembangan Desa Wisata Pujon Kidul," (Skripsi Program Studi Sosiologi, Universitas Muhammadiyah Malang, 2019), 77-78.
} 
Padahal sebelumnya masyarakat meragukan manfaat program desa wisata. ${ }^{24}$

Berdasarkan penjabaran di atas maka fokus studi ini adalah mendeskripsikan peran komponen sistem sosial dalam proses difusi inovasi program desa wisata Pujon Kidul, Kabupaten Malang mulai tahun $2005{ }^{25}$ hingga tahun 2016. Ada beberapa studi yang telah membahas tentang difusi inovasi. Di antaranya berjudul "Difusi Inovasi Program Sos Children Villages" ${ }^{26}$, "Difusi Inovasi Program Bank Sampah" 27, dan "Sosialisasi Inovasi Badan Usaha Milik Desa (Bumdes) Tirta Mandiri Oleh Pemerintah Desa Ponggok, Klaten Dengan Pendekatan Teori Difusi Inovasi" ${ }^{28}$. Ketiga studi sebelumnya meneliti difusi inovasi pada aspek strategi komunikasi, karakter inovasi dan tahapan difusi inovasi. Sedangkan pada studi ini lebih berfokus pada menguraikan peranan masing-masing komponen sistem sosial dalam proses difusi inovasi.

Ada juga artikel ilmiah yang menjadikan desa wisata Pujon Kidul sebagai objek kajian. Judulnya "Keterlibatan Karang Taruna Dalam Pemberdayaan Masyarakat Desa," 29 "Optimalisasi peran Bumdes dalam

${ }^{24}$ Nadiasari dan Nurhadi, "Pengorganisasian Kelompok Sadar Wisata Melalui Program Desa Wisata di Desa Pujon Kidul," jurnal pendidikan nonformal, Vol. 14 No. 2 (2019): 104.

25 Perjuangann Udi Hartoko Membangun Desa Wisata Pujon Kidul, 00:58-01-15, Video Artikel Internet, diunggah oleh "Medcom", https://www.medcom.id/embed/MkMnRXvK. (diakes 7 Juni, 2020)

26 Adelya Mahgda Herera Maharani Putri, "Difusi Inovasi Program Sos Children Villages (Studi Deskriptif Kualitas Penyebaran Dan Penerimaan Inovasi Program Pemberdayaan Masyarakat SOS Children's Villages Di Kecamatan Banyumanik Kabupaten Semarang)," (Skripsi Program Studi Ilmu Komunikasi, Universitas Muhammadiyah Surakarta, 2018).

${ }^{27}$ Media Sucahya dan Sigit Surahman, "Difusi Inovasi Program Bank Sampah", Jurnal IImu Komunikasi, Vol. 08, No.01 (2017).
Pengembangan Potensi Ekonomi Lokal sebagai Pilar Perekonomian Desa Pujon Kidul Kecamatan Pujon Kabupaten Malang," 30 "Pengorganisasian Kelompok Sadar Wisata Melalui Program Desa Wisata di Desa Pujon Kidul," ${ }^{31}$ dan "Pemberdayaan Ekonomi Masyarakat Desa Dalam Memenuhi Aspek Muqashid Syariah Melalui Pendekatan Asset Based Community Developement," ${ }^{32}$ Kajian sebelumnya terkait dengan desa wisata Pujon Kidul tidak membahas teori komponen sistem sosial. Sedangkan studi ini memiliki fokus kajian pada komponen sistem sosialnya. Belum ditemukan studi yang membahas tentang peran komponen sistem sosial dengan objeknya adalah program desa wisata Pujon Kidul.

Metodologi dalam studi ini menggunakan metode kualitatif. Teknik dalam penggalian datanya memakai metode dokumentasi, yaitu melakukan penelusuran berbagai data terkait pada beberapa sumber utama berikut: (a) Video Youtube yang berjudul

\footnotetext{
${ }^{28}$ Fitria Sabilla, "Sosialisasi Inovasi Badan Usaha Milik Desa (Bumdes) Tirta Mandiri Oleh Pemerintah Desa Ponggok, Klaten Dengan Pendekatan Teori Difusi Inovasi," (Skripsi Program Studi IImu Komunikasi, Universitas Muhammadiyah Surakarta, 2018).

29 Hastiti, "Keterlibatan Karang Taruna Dalam Pemberdayaan Masyarakat."

30 Qori Rusdiana, “Optimalisasi peran BUMDes dalam Pengembangan Potensi Ekonomi Lokal sebagai Pilar Perekonomian Desa Pujon Kidul Kecamatan Pujon Kabupaten Malang," (Skripsi Program Studi ekonomi Syariah, IAIN Tulungagung, 2019).

${ }^{31}$ Nadiasari dan Nurhadi, “Pengorganisasian Kelompok Sadar Wisata Melalui Program Desa Wisata di Desa Pujon Kidul."

32 Hidayatullah "Pemberdayaan Ekonomi Masyarakat Desa Dalam Memenuhi Aspek Maqashid Syariah Melalui Pendekatan Asset Based Community Development."
} 
"Semangat Pujon". ${ }^{33}$ (b) Video Youtube wawancara Udi Hartoko pada acara Kick Andy. ${ }^{34}$ (c) Website resmi desa Pujon Kidul yang bernama "Sistem Informasi Elektronik Desa wisata Pujon Kudul". ${ }^{35}$ Dan sumber penunjang seperti (a) Skripsi Raisha Hastiti berjudul "Keterlibatan Karang Taruna Dalam Pemberdayaan Masyarakat Desa." (b) Skripsi Qori Rusdiana berjudul "Optimalisasi peran Bumdes dalam Pengembangan Potensi Ekonomi Lokal sebagai Pilar Perekonomian Desa Pujon Kidul Kecamatan Pujon Kabupaten Malang." (c) Jurnal Nadiasari dan Nurhadi berjudul "Pengorganisasian Kelompok Sadar Wisata Melalui Program Desa Wisata di Desa Pujon Kidul." (d) Tesis Wildan Arif Hidayatullah berjudul "Pemberdayaan Ekonomi Masyarakat Desa Dalam Memenuhi Aspek Muqashid Syariah Melalui Pendekatan Asset Based Community Developement." Penggunaan berbagai sumber data tersebut karena kredibel di mana sumber tersebut berasal dari hasil studi dan dokumentasi video secara langsung. Selain itu juga relevan untuk dijadikan sebagai sumber data dalam menjawab rumusan masalah. Validasi datanya menggunakan teknik triangulasi pada berbagai sumber data tersebut. Analisis datanya menggunakan model Miles dan Huberman, yaitu mereduksi, mengklasifikasi, menganalisis, hingga menyimpulkan data. ${ }^{36}$

\footnotetext{
${ }^{33}$ Semangat Pujon, video Youtube, 01:34-18-34, di unggah oleh "Cafe Sawah," 5 Juli 2018. https://www.youtube.com/watch?v=E3Vyk166yss\&t= 407s (diakses 27 Desember, 2020)

${ }^{34}$ Perjuangan Udi Hartoko membangun Desa wisata Pujon Kidul, Video Artikel Internet, diunggah di oleh "medcom,"

https://www.medcom.id/embed/MkMnRXvK. (diakes 7 Juni, 2020)
}

\section{Komponen Sistem Sosial Dalam Proses Difusi Inovasi}

Difusi inovasi adalah usaha agar suatu gagasan atau produk baru, masuk dan diterima oleh masyarakat. ${ }^{37}$ Rogers mengatakan akibat objek difusi inovasi adalah sebuah masyarakat dan di dalam masyarakat terdapat komponen sistem sosial, maka sukses atau gagalnya proses difusi inovasi tergantung dari penerapan komponen sistem sosial. ${ }^{38}$ Komponen sistem sosial tersebut adalah anggota sistem sebagai penerima manfaat, agen pembaharu, tokoh masyarakat, saluran komunikasi, norma sistem, dan prinsip homophily-heterophily. ${ }^{39}$

Berikut penjelasan lebih detail pada enam komponen sistem sosial tersebut. Pertama, anggota sistem sebagai penerima manfaat. Mereka adalah kelompok di dalam masyarakat yang sengaja disasar sebagai penerima inovasi. Memanfaatkan variabel ini akan mendukung proses difusi inovasi. Alasannya adalah karakter dari berbagai kelompok yang ada di masyarakat cenderung berbeda-beda, termasuk di dalamnya karakter inovatif dan mudah dalam menerima inovasi. Kelompok yang paling mudah menerima inovasi disebut dengan kelompok inovator. Sedangkan kelompok yang paling susah menerima inovasi disebut dengan kelompok kolot. Pada poin inilah peranannya. Apabila aktor pemberdaya berhasil mengidentifikasi

\footnotetext{
${ }^{35}$ Admin, "Sistem Informasi Elektronik," SIE Pujon Kidul, https://sie.pujonkidul.desa.id/penduduk.php (diakses 7 juni 2020).

${ }^{36}$ Ismail Nurdin dan Sri Hartati, Metodologi Penelitian Sosial (Surabaya: Media Sahabat Cendekia, 2019), 206. ${ }^{37}$ Rogers, Diffusion Of Innovation Fifth Edition, 40-41.

38 Ibid., 66-67.

39 Ibid., 60-66.
} 
kelompok inovator dan menyasarnya sebagai kelompok pertama penerima inovasi, maka inovasi akan mudah diterima akibat karakter inovatifnya. Selanjutnya Ketika kelompok inovator ini menerima inovasi, mereka bisa mempengaruhi penerimaan masyarakat yang selainnya dengan cara menjadi objek percontohan sebagai masyarakat yang telah menerima inovasi. ${ }^{40}$ Cara menemukan kelompok inovator adalah dengan mencari kelompok yang memiliki pendidikan yang tinggi dan ekonomi yang mapan. ${ }^{41}$

Kedua, adalah agen pembaharu. Agen pembaharu adalah aktor yang dengan sengaja menyebarkan inovasi kepada masyarakat. Berikut penjelasan lebih detailnya. Pertama, peran dalam keputusan inovasi opsional. Artinya berbagai peran yang dilakukan oleh agen pembaharu yang bisa mempengaruhi keputusan untuk menerima inovasi melalui masing-masing individunya secara langsung, bukan melalui keputusan kelompok. (a) Membangkitkan keputusan untuk berubah. Artinya berusaha mengubah paradigma masyarakat agar mau mengubah nasib mereka; (b) Mengadakan hubungan untuk perubahan. Artinya berusaha membentuk hubungan saling percaya dengan masyarakat; (c) Mendiagnosis masalah. Artinya berusaha melakukan pemetaan berbagai masalah agar inovasi bisa kontekstual dengan kondisi masyarakat; (d) Menciptakan motivasi untuk berubah. Artinya memotivasi kepada masyarakat agar mereka mau menerima inovasi; (e) Merencanakan tindakan pembaharuan. Artinya berusaha membuat strategi rencana penerapan inovasi; (f) Memelihara program dari kemacetan.

40 Ibid., 321-328.

41 Ibid., 331.
Artinya berusaha agar masyarakat yang telah menerima tidak bosan dengan inovasi; dan (g) Mencapai hubungan termal. Artinya berusaha agar masyarakat yang telah menerima inovasi bisa mandiri dalam menjalankan inovasi. ${ }^{42}$

Selanjutnya adalah peran dalam keputusan inovasi kolektif. Artinya berbagai peran yang dilakukan oleh agen pembaharu yang bisa mempengaruhi keputusan untuk menerima inovasi melalui keputusan dalam kelompok, semisal melalui musyawarah, rapat, atau rembug warga. (a) menstimulus inovasi. Artinya berusaha untuk mengenalkan inovasi pada forum diskusi masyarakat desa semisal pada musyawarah desa; (b) Membantu mempertimbangkan keputusan yang paling efektif. Artinya berusaha menunjukkan kepada peserta musyawarah bahwa inovasi yang dibawakan adalah yang paling efektif dibanding yang selainnya dengan menyampaikan berbagai kelebihannya, semisal menjelaskan bahwa inovasi bisa meningkatkan pendapatan desa. ${ }^{43}$

Terakhir, peran dalam keputusan inovasi otoritas. Artinya usaha untuk mempengaruhi keputusan menerima inovasi melalui jalur birokrasi. (a) Mengenalkan inovasi pada pihak otoritas. Artinya berusaha agar otoritas setempat semisal kepala desanya mengenali inovasi yang dibawakan; (b) Mempersuasikan inovasi ke pihak otoritas. Artinya setelah memperkenalkan, agen pembaharu berusaha agar otoritas yang bersangkutan, semisal kepala desanya yakin untuk

42 Ibid., 412-414.

43 Ibid., 63-65. 
menerapkan inovasi sebagai program desa. ${ }^{44}$

Ketiga, adalah tokoh masyarakat. Tokoh masyarakat adalah individu yang ada dalam masyarakat namun memiliki keistimewaan secara sosiologis. Mereka adalah orang yang mudah dipercaya oleh masyarakat, entah itu perbuatan atau perkataan mereka. Dalam hal komunikasi, ia selalu menjadi sosok opinion leader atau orang yang mudah mengontrol jalannya pembicaraan. Keistimewaan dari tokoh masyarakat tersebut bisa mendukung proses difusi inovasi. Apabila agen pembaharu berhasil mengidentifikasi tokoh masyarakat kemudian memberikan perhatian khusus kepadanya agar mau menerima inovasi, maka hal ini bisa mempercepat penerimaan masyarakat. Tokoh masyarakat memiliki beberapa ciri-ciri sosiologis. Pertama, mereka banyak dikenal sebagai orang yang berjasa terhadap desa. Kedua, memiliki hubungan sosial yang luas ke dalam atau ke luar desa. Ketiga, terkenal terpandang karena berpendidikan, berwawasan luas, dan memiliki ekonomi yang mapan jika dibandingkan dengan mayoritas masyarakat yang selainnya. ${ }^{45}$

Keempat, adalah saluran komunikasi. Saluran komunikasi adalah berbagai cara yang digunakan sebagai media untuk menyebarkan inovasi. Terdapat dua macam saluran komunikasi, di antaranya adalah saluran komunikasi interpersonal dan media massa. Berikut adalah penjelasan detailnya. Saluran komunikasi interpersonal artinya saluran komunikasi yang menuntut antara komunikan dan komunikator untuk bertemu secara langsung. Contohnya adalah

44 Ibid.

45 Ibid., 62-63. musyawarah, diskusi, atau rembug desa. Saluran komunikasi interpersonal cocok untuk proses difusi inovasi pada tahap persuasi karena proses feedback antar pembicaranya bisa berjalan dengan cepat. Sehingga mudah bagi komunikator untuk meyakinkan komunikannya. Saluran komunikasi ini juga cocok untuk masyarakat tradisional yang cenderung tidak diperantarai oleh teknologi ketika berkomunikasi. ${ }^{46}$

Selanjutnya adalah saluran komunikasi media massa. Saluran komunikasi ini menuntut adanya perantara dalam proses komunikasinya. Perantara tersebut bisa dalam bentuk media cetak seperti majalah atau buletin. Bisa juga dalam bentuk media elektronik seperti laptop atau handphone. Saluran komunikasi media massa cocok untuk proses pengenalan inovasi karena dalam waktu singkat bisa mengirim pesan ke banyak orang. ${ }^{47}$

Kelima, adalah norma sistem. Norma sistem adalah aturan tidak tertulis yang ada dalam masyarakat. Norma sistem ini menjadi pedoman hidup masyarakat agar tidak melakukan atau harus melakukan suatu perbuatan/perkataan. Apabila melakukan akan dianggap baik, sebaliknya melanggar akan mendapatkan sanksi sosial. Dalam konteks difusi inovasi, ada dua norma sistem yang berperan mendukung maupun menghambat proses difusi inovasi. Norma sistem tradisional bisa menghambat akibat karakter masyarakatnya. Pertama, Akibat karakter masyarakatnya yang tidak mengorientasikan hidupnya kepada perubahan, maka sulit bagi mereka untuk menerima perubahan. Kedua, akibat

${ }^{46}$ Ibid., 245-248

47 lbid. 
pendidikan dan penggunaan teknologi yang rendah, maka susah bagi mereka untuk memahami/menyerap hal-hal baru apalagi yang diperantarai oleh teknologi. Ketiga, akibat hubungan kekerabatan antar masyarakatnya cukup kuat, maka susah bagi mereka untuk menerima suatu inovasi sebelum inovasi ini diterima oleh mayoritas masyarakat. Berbeda dengan masyarakat dengan karakter modern. Akibat mereka yang mengorientasikan hidupnya untuk perubahan, cenderung berpendidikan baik dan memiliki akses teknologi yang baik, mudah bagi mereka untuk menerima perubahan. Mereka mampu menyerap perubahan lebih cepat selama memang dianggap solutif tanpa harus tergantung dengan keputusan individu lainnya. ${ }^{48}$

Keenam, adalah prinsip homophilyheterophily. Variabel ini membicarakan tentang derajat sama dan berbeda antara agen pembaharu dengan masyarakat yang muncul secara alamiah. Disebut homophily apabila ada banyak kesamaan antara agen pembaharu dengan masyarakat. Sebaliknya disebut heterophily apabila ada banyak derajat perbedaan antara agen pembaharu dengan masyarakat. Kedua prinsip ini memiliki peranan terhadap proses difusi inovasi. Makin homophily antara agen pembaharu dengan masyarakat, maka akan menjadi salah satu faktor penunjang dalam mempercepat proses difusi inovasi. Alasannya, orang-orang yang memiliki banyak kesamaan semisal sama-sama bersuku jawa, beragam Islam, berasal dari

\footnotetext{
48 Ibid., 61-62.

49 Ibid., 348-350.

50 Admin, "sistem informasi elektronik," SIE Pujon Kidul, https://sie.pujonkidul.desa.id. (Diakses 13 juni 2020)

${ }^{51}$ Ahsani Taqwiem Dan Ahmad Roziq Zakaria, "Wisata Halal Untuk Mencapai Pembangunan Ekonomi
}

desa yang sama, atau memiliki visi dan misi yang sama, maka mereka akan lebih mudah untuk saling percaya satu sama lainnya. Apabila kepercayaan antara masyarakat dengan agen pembaharu sudah terbentuk, maka akan lebih mudah bagi masyarakat untuk percaya dengan inovasi yang dibawakan. Sebaliknya, makin heterophily antara agen pembaharu dengan masyarakat, maka akan menjadi faktor penunjang yang memperlambat proses difusi inovasi. Semisal bahasa yang berbeda akan memperlambat proses komunikasi. Agama yang berbeda juga bisa berpotensi menjadikan masyarakat curiga dengan inovasi yang dibawakan akibat inovasi hanya dianggap sebagai media penyebaran agama semata oleh agen pembaharu. ${ }^{49}$

\section{Profil Program Desa Wisata Pujon Kidul}

Program desa wisata Pujon Kidul adalah program pemberdayaan yang bertujuan sebagai sarana edukasi bagi masyarakat untuk melakukan berbagai kegiatan seru seperti memetik sayur, pengolahan susu, wahana outbond, air terjun dan wisata alam lainnya. ${ }^{50}$ Program ini dinilai sebagai program wisata halal karena menerapkan prinsip maqāshid asy-syarīah dalam kegiatan pemberdayaanya. ${ }^{51}$ Kepala desa Pujon Kidul dijabat oleh Udi hartoko. la memiliki visi menjadikan desa Pujon Kidul menjadi sebuah desa wisata melalui program ini..$^{52}$ Udi Hartoko adalah orang asli Desa Pujon Kidul yang prihatin dengan

Masyarakat Desa Dan Tujuan Muqashid Syariah (Stud Kasus Pada Desa Wisata Pujon Kidul, Kabupaten Malang, Jawa Timur)," El-Aswaq, vol. 1, No. 1 (2020): 1.

52 Damayanti, "Peran Bumdes Dalam Pengembangan Desa Wisata Pujon Kidul," 94. 
berbagai permasalahan desa seperti fenomena pemuda yang menganggur, suka melakukan sabung ayam, mabuk-mabukan, hingga banyak para pemuda yang merantau ke kota untuk mencari pekerjaan. Padahal Udi menyadari bahwa di desanya masih ada potensi ekonomi, alam, dan budaya yang bisa dimanfaatkan untuk memberdayakan dan meningkatkan perekonomian warga desa Pujon Kidul. Sehingga ia memutuskan untuk meninggalkan pekerjaannya sebagai manajer vila di kota Batu dan fokus untuk memberdayakan masyarakat desa melalui program ini. ${ }^{53}$

Desa Pujon Kidul terletak di Kecamatan Pujon, Kabupaten Malang, Jawa Timur. Secara geografis, desa ini terletak di daerah pegunungan dengan potensi alam yang indah, budaya khas pedesaan yang masih terjaga, dan perekonomian yang banyak ditopang pada sektor pertanian dan peternakan. ${ }^{54}$ Secara pendidikannya, desa ini mayoritas lulusan sekolah dasar, di mana tujuh puluh lima persen penduduknya berpendidikan SD ke bawah. ${ }^{55}$

\section{Karakter dan peran Komponen Sistem Sosial Dalam Proses Difusi inovasi Program Desa Wisata Pujon Kidul}

Pertama, anggota sistem sebagai penerima manfaat. Secara umum, Kelompok pertama yang disasar oleh Udi Hartoko untuk dikenalkan program ini adalah kelompok karang taruna desa. Berikut beberapa faktanya: (a) Pada tahun 2005, ia sudah mengenalkan inovasi ini kepada para pemuda ketika mereka sedang istirahat bersama selepas mencari kayu bakar. la menyatakan bahwa alam desanya cukup indah dan harus dimanfaatkan keindahannya; ${ }^{56}$ Ini adalah langkah awal agar para pemuda bisa mengenal konsep desa wisata, yaitu dengan dikenalkan impian agar memanfaatkan keindahan alam desa (b) Lalu pada tahun 2011, setelah la menjabat sebagai kepala desa, ia pun tetap menyasar kelompok karang taruna sebagai kelompok pertama penerima inovasi. Udi menegaskan bahwa ia memang sengaja menyasar kelompok karang taruna Desa Pujon Kidul sebagai langkah awalnya ketika sudah menjabat sebagai seorang kepala desa. ${ }^{57}$

Keunikan dari karakter kelompok pemuda ini adalah mereka bukanlah kelompok yang berpendidikan tinggi. Rata-rata pendidikan

\footnotetext{
56 Perjuangan Udi Hartoko membangun Desa wisata Pujon Kidul, Video Artikel Internel 01:00-01:42, diunggah di oleh "medcom," https://www.medcom.id/embed/MkMnRXvK. (diakes 7 Juni, 2020)

57 Doni Asyar, "Ini Rahasia Pak Kades Udi Hartoko Kembangkan Desa Wisata Pujon Kidul Malang," Radio Idola, https://www.radioidola.com/2017/ini-rahasiapak-kades-udi-kembangkan-desa-wisata-pujon-kidulmalang. (diakes 7 Juni, 2020)
} 
mereka hanyalah lulusan SMP saja. Secara ekonomi, mereka juga bukanlah kelompok yang mapan. Pada awalnya mereka sering melakukan sabung ayam, kumpul-kumpul tidak penting ketika malam, atau melakukan balapan liar ketika bulan Ramadhan. ${ }^{58}$ Padahal secara teori, disebutkan kelompok inovator atau kelompok pertama yang disasar kecenderungan memiliki karakter pendidikan dan ekonomi yang mapan. Namun walaupun pemuda karang taruna tidak memiliki ekonomi dan pendidikan yang baik, ia tetap dipilih sebagai kelompok inovator.

Analisisnya hal ini disebabkan oleh beberapa faktor, di antaranya adalah: (a) karakter dari seorang pemuda. Seorang pemuda secara psikologis memiliki karakter suka dengan tantangan dan hal-hal baru akibat dorongan rasa ingin tahu yang tinggi. ${ }^{59}$ Dan inovasi program desa wisata adalah hal baru. Maka unsur kebaruan tersebut akan mendorong para pemuda untuk mau menerima inovasi; (b) Pemuda Pujon Kidul memiliki karakter cinta dengan desanya. Ketika mereka memiliki kecintaan dengan desa, maka mereka akan terdorong untuk menerima inovasi sebagai bentuk pengabdian dalam membangun desa. ${ }^{60}$

Pemuda karang taruna berperan sebagai objek percontohan penerapan program bagi masyarakat pada saat awal-awal pengenalan inovasi. Walaupun kelompok pemuda ini tidak memiliki ekonomi dan pendidikan yang baik, namun ketika diawal mereka disasar sebagai kelompok pertama penerima

58 Hastiti, “Keterlibatan Karang Taruna Dalam Pemberdayaan Masyarakat Desa," 79.

${ }^{59}$ Siti Aesyah, Masa Puber Saat Remaja (Semarang: Mutiara Aksara, 2019), 12.

60 Hastiti, "Keterlibatan Karang Taruna Dalam Pemberdayaan Masyarakat Desa," 98. inovasi, mereka tetap berhasil mendorong kelompok masyarakat yang selainnya untuk mau berpartisipasi dalam program.

Indikasinya adalah pada awal kali yang menerima inovasi hanya para pemuda. Kemudian, warga yang awalnya menolak justru mau berpartisipasi dalam program. Hal ini akibat adanya contoh penerapan yang dilakukan oleh pemuda karang taruna. ${ }^{61}$

Efeknya Berbagai ketakutan dan bayangan mereka akan program yang tidak realistis untuk dilakukan hilang karena mereka bisa menilai sendiri bahwa ternyata aktivitas dari program ini yaitu edukasi pertanian, peternakan, dan pementasan seni adalah aktivitas yang dekat dengan kesehariannya.

Kedua, berdasarkan penelusuran data menunjukkan bahwa agen pembaharu desa Pujon Kidul ialah Udi Hartoko. Hal itu diwujudkan dalam paparan berikut. Pertama karakter seorang agen pembaharu dalam keputusan opsional: (a) Membangkitkan kebutuhan untuk berubah. Usaha yang dilakukan adalah melakukan penyadaran dengan cara menyampaikan agar masyarakat mau mengenal tentang konsep dana desa karena dana desa ini bisa digunakan untuk modal pembangunan. ${ }^{62}$ la juga memberikan pengertian agar masyarakat sadar bahwa untuk mengatasi masalah sosial yang ada di desa, maka diperlukan kerja sama dan solidaritas dari semua anggota masyarakat untuk mau

61 Hastiti, “Keterlibatan Karang Taruna Dalam Pemberdayaan Masyarakat Desa, 101-102.

62 A, Sunariyanto dan fiffudin, "Implementasi Kebijakan Dana Desa Untuk Pengembangan Potensi Desa,"40. 
menerima program desa wisata yang baru saja dikenalkan ini. ${ }^{63}$

Usaha ini berperan dalam mengubah paradigma agar lebih terbuka dengan perubahan pada tahap difusi paling awal yaitu pengenalan. Penerimaan masyarakat akibat paradigma terbuka ditunjukkan dengan data peningkatan jumlah dan variatifnya partisipasi dari masyarakat seperti partisipasi buah pikir, tenaga fisik, partisipasi keterampilan dan kemahiran, dan partisipasi harta benda. ${ }^{64} \mathrm{Hal}$ ini disebabkan oleh perubahan paradigma dari masyarakat yang sudah terbuka dengan perubahan. Keberhasilan peran ini diakibatkan ketepatan dalam memandang substansi masalah.

(b) Mengadakan hubungan untuk perubahan. Sebagai kepala desa, ia menyepakati bahwa kesejahteraan masyarakatlah yang diutamakan dan menyepakati hal ini sebagai visi berdirinya badan usaha milik desa (Bumdes). ${ }^{65}$ Artinya secara tidak langsung ia berusaha membangun kepercayaan dengan mengutamakan masyarakat dalam pembentukan visi ini. Selain itu mereformasi lembaga pemerintah desa dengan menerapkan prinsip sapta pesona wisata dan pemerintahan yang solid, speed, dan smart (3S). 66 Dianalisis, melakukan reformasi maknanya berusaha meyakinkan masyarakat agar percaya dengan lembaga

63 Damayanti, "Peran Bumdes Dalam Pengembangan Desa Wisata Pujon Kidul," 90.

${ }^{64}$ Prabowo, Hamid dan Prasetya, "analisis partisipasi masyarakat dalam pengembangan desa wisata," 21.

65 Rusdiana, "Optimalisasi peran BUMDes dalam Pengembangan Potensi Ekonomi Lokal sebagai Pilar Perekonomian Desa Pujon Kidul Kecamatan Pujon Kabupaten Malang," 79.

${ }^{66}$ Admin, "Tips Membangun Desa Wisata Ala Pujon Kidul." desa bisa, https://www.desabisa.com/tips- desa dan mau menyukseskan program desa. la juga menaruh perhatian khusus kepada kelompok pemuda karang taruna desa. la menggunakan komunikasi yang bersahabat agar terbentuk kedekatan dan tidak membangun jarak antara pemuda dengan Udi Hartoko. ${ }^{67}$ Lalu terhadap jajaran pemerintahannya, ia meminta agar mereka jujur dan transparan agar pemerintahan bisa dipercaya oleh masyarakat. ${ }^{68}$

Berbagai usaha di atas adalah bentuk membangun hubungan saling percaya karena prinsipnya Udi sedang meyakinkan masyarakat bahwa segala hal yang berkaitan dengan program desa wisata Pujon Kidul mulai dari lembaga Bumdes, lembaga pemerintahan, hingga inisiatornya sendiri, semua bisa dipercaya dan terbentuk kepercayaan bahwa program ini memang hendak menyejahterakan masyarakat.

Aktifitas ini berperan menjadikan masyarakat percaya dengan agen pembaharu pada tahap awal pengenalan inovasi. Akibat kepercayaan masyarakat telah terbangun, masyarakat mau menerima inovasi dengan partisipasi yang beragam, mulai dari partisipasi buah pikir hingga harta benda. ${ }^{69}$

Keberhasilan peran ini karena pemahaman Udi bahwa masyarakat desa Pujon Kidul adalah stakeholder yang menjadi objek pemberdayaan dan Bumdes serta Pemda

membangun-desa-wisata-ala-pujon-kidul. (diakses tanggal 7 Juni, 2020)

67 A, Sunariyanto dan fiffudin, "Implementasi Kebijakan Dana Desa Untuk Pengembangan Potensi Desa,"44.

68 Triaryanti, "Collaborative Governance Dalam Pengelolaan Bumdes Di Desa Wisata Pujon Kidul, Kecamatan Pujon, Kabupaten Malang," 11.

69 Ibid. 
Pujon Kidul adalah subjek pemberdaya dalam rangkaian proses difusi inovasi program desa wisata Pujon Kidul. Dengan pijakan ini, ia mempu memfokuskan perhatiannya untuk selalu membangun dan menjaga kepercayaan dari objek pemberdaya. Tidak hanya itu, la juga menyadari bahwa para pemuda adalah kelompok inovator. Hingga akhirnya ia pertama kali membangun hubungan kepercayaan dengan kelompok pemuda ini.

Pembangunan kepercayaan terhadap agen pembaharu pada desa Pujon dilakukan tidak hanya terhadap individunya, namun menggunakan lembaga terkait seperti Bumdes dan Pemerintah desa Pujon Kidul. Prinsipnya, selama individu atau lembaga itu berinteraksi dengan masyarakat dalam difusi inovasi, maka penting juga untuk membangun kepercayaan kepada keduanya.

(c) Mendiagnosis masalah. Berbagai upaya yang dilakukan adalah melakukan pemetaan masalah sekaligus potensi dengan menanyai seluruh warga desa dari RT 1 hingga RT $18 \mathrm{di}$ tiga dusun di bawah naungan Desa Pujon Kidul. ${ }^{70}$ Akhirnya ditemukan beberapa masalah desa yaitu pengangguran, kenakalan remaja, pendidikan rendah, hingga permasalahan ekonomi. ${ }^{71} \mathrm{Di}$ sisi lain ditemukan juga potensi desa seperti keindahan alam, kekayaan budaya desa, dan aktivitas pertanian dan peternakan yang menarik bagi penduduk kota. ${ }^{72}$

\footnotetext{
70 Ibid., 3-4.

71 Hidayatullah "Pemberdayaan Ekonomi Masyarakat Desa Dalam Memenuhi Aspek Maqashid Syariah Melalui Pendekatan Asset Based Community," 109110.

72 Ibid., 90.

73 Hidayatullah "Pemberdayaan Ekonomi Masyarakat Desa Dalam Memenuhi Aspek Maqashid Syariah
}

Pemetaan ini berperan dalam menjadikan produk desa wisata bisa kontekstual dengan masyarakat pada saat tahap perencanaan inovasi. Akibat pemetaan yang berbasis masalah dan potensi, program ini bisa kontekstual dengan desa. ${ }^{73}$ Inovasi yang kontekstual mampu mendorong penerimaan masyarakat. ${ }^{74}$

Akibat masalah yang diangkat adalah masalah nyata desa, hal ini mampu mendorong masyarakat untuk memunculkan kesimpulan bahwa menerima inovasi sama dengan menyelesaikan masalah masyarakat. Dan akibat inovasinya berbasis potensi asli desa, maka bisa mempercepat penerimaan karena memudahkan proses masyarakat dalam memahami dan menjalankan inovasi.

(d) Menciptakan motivasi untuk berubah pada diri klien. Berbagai usaha yang dilakukan adalah pertama, Udi menjelaskan bahwa program desa wisata bisa meningkatkan pendapatan desa. ia menjelaskan logika bahwa dengan adanya program ini, masyarakat bisa menjual berbagai produk hasil alam desa dengan lebih mahal kepada wisatawan. Sehingga ada dana lebih untuk menyelesaikan masalah kelangkaan air yang dikeluhkan warga. ${ }^{75}$ Selanjutnya dengan menghibahkan tanah yang ia miliki untuk modal awal program bagi para pemuda agar mau melaksanakan inovasi. ${ }^{76}$ Ketiga, Udi Hartoko memotivasi keraguan warga desa karena

Melalui Pendekatan Asset Based Community Development, 90.

${ }^{74}$ Rogers, Diffusion Of Innovation Fifth Edition, 412414.

75 Hastiti, "Keterlibatan Karang Taruna Dalam Pemberdayaan Masyarakat Desa," 127-128.

76 Ibid., 65-66. 
menganggap kas desa tidak akan cukup untuk mengadakan program ini. la menyelesaikan masalah ini dengan cara mengajak seluruh warga untuk iuran. Jadi warga diminta untuk melakukan patungan sebagai modal awal pengadaan program. Hingga akhirnya terkumpul dana kurang lebih empat puluh hingga enam puluh jutaan. ${ }^{77}$

Kegiatan ini berperan dalam mendorong masyarakat agar termotivasi untuk menerima inovasi pada tahap mempersuasikan inovasi. Keberhasilan Udi dalam memotivasi akibat pemahaman Udi terhadap masalah nyata dan aspirasi masyarakat. Yang kemudian hal tersebut dihubungkan dengan inovasi sebagai jawaban masalahnya. Hal ini ditandai dengan data yang menyatakan bahwa akibat masyarakat yang mendapatkan logika penjelasan bahwa menerima inovasi bisa menyelesaikan masalah kelangkaan air, masyarakat menjadi yakin dengan inovasi. ${ }^{78}$

(e) Merencanakan tindakan pembaharuan. Perencanaan ini adalah proses pembuatan strategi program desa wisata berdasarkan pemetaan masalah dan potensi. Usaha yang dilakukan adalah melakukan dialog dengan warga secara informal. Di sana warga bebas berpendapat tentang strategi program tersebut. ${ }^{79}$ Akhirnya, perencanaan ini menghasilkan beberapa strategi program. Pertama, mengadakan wisata edukasi pertanian. Teknisnya adalah wisatawan akan diajak bertani dengan langsung dibimbing

77 Ibid., 128-129.

78 Hastiti, “Keterlibatan Karang Taruna Dalam Pemberdayaan Masyarakat Desa, 65-66.

79 lbid., 77-79.

${ }^{80}$ Nadiasari dan Nurhadi, “Pengorganisasian Kelompok Sadar Wisata Melalui Program Desa Wisata di Desa Pujon Kidul," 104. oleh petani desa. Kedua, pengadaan wisata edukasi peternakan. Teknisnya adalah wisatawan diajak belajar merawat hewan ternak dan memeras susu dengan langsung diajari oleh peternak desa. Ketiga, wisata edukasi UMKM pengolahan susu. Wisatawan akan diajak melihat bagaimana proses pengolahan susu menjadi dodol, krupuk susu, permen susu, hingga susu rasarasa. ${ }^{80}$ Keempat, wisata budaya dengan mementaskan berbagai kesenian khas desa semisal campursari, wayang wong, hingga sholawatan khas desa. ${ }^{81}$

Upaya ini berperan dalam mendesain inovasi agar lebih jelas bagi masyarakat pada tahap perencanaan inovasi. Setelah program telah diperjelas hingga tataran teknis, maka abstraksi masyarakat tidak meluas. Masyarakat mudah menilai bahwa ternyata program ini sangat dekat dengan keseharian mereka. Sehingga mendorong masyarakat untuk menerima inovasi. Hal tersebut diindikasikan dengan data yang menyatakan bahwa musyawarah bersama warga yang membahas teknis perencanaan tersebut menyebabkan masyarakat mau berpartisipasi dalam pengadaan edukasi wisata pertanian, peternakan, dan UMKM. ${ }^{82}$

(f) Memelihara program pembaharuan dan mencegah dari kemacetan. Berbagai usaha yang dilakukan adalah dengan melakukan evaluasi program secara berkala. Ada evaluasi tiga bulanan, evaluasi satu bulanan, hingga evaluasi mingguan. Evaluasi ini akan menjadi pijakan dalam pembuatan berbagai

\footnotetext{
81 Damayanti, "Peran Bumdes Dalam Pengembangan Desa Wisata Pujon Kidul," 95.

${ }^{82}$ Nadiasari dan Nurhadi, "Pengorganisasian Kelompok Sadar Wisata Melalui Program Desa Wisata di Desa Pujon Kidul," 104.
} 
perubahan yang diperlukan. ${ }^{83}$ Lalu, pengadaan kafe sawah sebagai bentuk pembaharuan pada variasi wahana. Pembaharuan ini muncul pada tahun 2016. Konsep yang barunya adalah pengunjung bisa menikmati makanan dan minumam khas desa dengan dikelilingi hamparan sawah sebagai konsep kafenya. ${ }^{84}$

Peran ini mampu menjaga motivasi masyarakat untuk tetap menerima inovasi dengan cara membuat program ini tidak membosankan sehingga terjaga keputusan penerimaannya. Alasannya, berbagai unsur kebaharuan seperti dekorasi tema wisata yang berubah, pembuatan menu makanan yang berbeda, hingga proses menemukan solusi atas berbagai masalah yang tidak sama di tiap bulannya, menyebabkan masyarakat tidak bosan. Kesan rutinitas dan aktivitas yang membosankan ini tidak akan terasa akibat berbagai dinamika pembaharuan. Dengan begitu keputusan untuk menerima inovasi tidak akan berubah. Data menunjukkan bahwa kegiatan pengembangan dan evaluasi produk memang dilakukan untuk menjaga eksistensi program. $^{85}$

(g) Mencapai hubungan termal. Berbagai usaha untuk memandirikan masyarakat adalah melakukan berbagai pembekalan seperti sosialisasi tentang konsep sapta pesona wisata; Pengadaan pelatihan mengenai konsep wisata berbasis komunitas; Sosialisasi peraturan desa

83 Triaryanti, "Collaborative Governance Dalam Pengelolaan Bumdes Di Desa Wisata Pujon Kidul, Kecamatan Pujon, Kabupaten Malang," 16.

84 Hastiti, "Keterlibatan Karang Taruna Dalam Pemberdayaan Masyarakat Desa," 96.

85 Rusdiana, "Optimalisasi peran BUMDes dalam Pengembangan Potensi Ekonomi Lokal sebagai Pilar Perekonomian Desa Pujon Kidul Kecamatan Pujon Kabupaten Malang," 79. tentang pengembangan kawasan, usaha wisata, atraksi wisata, serta penunjang wisata lainnya yang ada di wilayah Desa Pujon Kidul yang dilakukan oleh Kades secara langsung; Mengirim beberapa pemuda desa untuk mengikuti pelatihan di luar desa; Hingga melakukan pelatihan secara langsung dengan berkumpul di salah satu rumah warga. ${ }^{86}$

Hal tersebut berperan menjaga keputusan penerimaan inovasi dari berbagai permasalaan yang bisa membuat masyarakat menyerah dan keluar dari partisipasinya. Alasannya adalah dengan memandirikan, masyarakat bisa lebih tahan terhadap dinamika masalah. Kemandirian masyarakat menjadikan mereka tidak akan mundur ketika menemui masalah Sebaliknya, mereka akan bertahan tetap berpartisipasi akibat berbagai pembekalan yang telah dilakukan sebelumnya. Sehingga keputusan menerima masyarakat tidak berubah menjadi perasaan tidak mampu lagi dalam menjalankan inovasi dan akhirnya memutuskan keluar. Hal ini dibuktikan dengan data bahwa berbagai pelatihan program wisata meningkatkan minat masyarakat terhadap inovasi program desa wisata Pujon Kidul. ${ }^{87}$

Selanjutnya, karakter seorang agen pembaharu dalam keputusan kolektif. Berbagai aktivitas yang dilakukan adalah pada tahun 2015 ia pertama kali memperkenalkan inovasi desa wisata agar

86 Rusdiana, "Optimalisasi peran BUMDes dalam Pengembangan Potensi Ekonomi Lokal sebagai Pilar Perekonomian Desa Pujon Kidul Kecamatan Pujon Kabupaten Malang," 79.

${ }^{87}$ Nadiasari dan Nurhadi, “Pengorganisasian Kelompok Sadar Wisata Melalui Program Desa Wisata di Desa Pujon Kidul," 104-105. 
menjadi program Bumdes pada momen musyawarah desa. ${ }^{88}$ Kemudian ia mempersuasikan kelebihan program ini dengan cara menunjukkan bahwa program bisa meningkatkan nilai jual potensi alam, budaya, dan ekonomi desa. Sehingga bisa meningkatkan kesejahteraan masyarakat. ${ }^{89}$

Berperan dalam mempercepat proses pengenalan dan persuasi inovasi program. Akibat disampaikan pada forum kolektif, hal ini menyebabkan proses pengenalan dan meyakinkan juga langsung banyak. Sehingga dalam satu waktu proses pengenalan dan persuasi, bisa lebih cepat sampai ke banyak orang. Bahkan ketika keputusan mayoritasnya adalah menyetujui program, hal ini akan mendorong masyarakat yang masih ragu dan menolak untuk ikut setuju juga akibat mengikuti keputusan bersama yang telah di sepakati bersama.

Bukti keberhasilan peran ini adalah Udi yang mengenalkan dan meyakinkan inovasi pada forum musyawarah desa, menyebabkan pada tahun 2015 program ini disetujui oleh masyarakat melalui Perdes No 6 tahun 2015. ${ }^{90}$ Padahal baru saja di tahun 2014 program ini dikenalkan ke masyarakat melalui pendirian Bumdes.$^{91}$

Terakhir, aktivitas yang menjadi karakter seorang agen pembaharu dalam keputusan otoritas. Ditemukan data bahwa tahun 2015, Program desa wisata Pujon kidul sudah resmi menjadi program pemerintah desa berdasarkan peraturan desa No. 6 Th.

88 lbid., 69.

89 Damayanti, "Peran Bumdes Dalam Pengembangan Desa Wisata Pujon Kidul," 77-78.

90 Rusdiana, "Optimalisasi peran BUMDes dalam Pengembangan Potensi Ekonomi Lokal sebagai Pilar Perekonomian Desa Pujon Kidul Kecamatan Pujon Kabupaten Malang," 69.
2015. ${ }^{92} \mathrm{Hal}$ ini bisa terjadi karena Udi sendirilah pemegang otoritas tersebut. ${ }^{93}$ Ini artinya secara tidak langsung Udi Hartoko sudah melakukan proses mengenalkan dan meyakinkan ke lingkungan birokrasi pemerintahan Desa Pujon Kidul karena ia sendiri adalah inisiator program sekaligus pejabat kepala Desa Pujon Kidul.

Berperan dalam mempercepat pengenalan dan persuasi akibat didifusikan ke pihak otoritas. Mengenalkan ke pihak otoritas artinya mengenalkan inovasi ke pihak yang memiliki kekuasaan dalam menentukan arah kebijakan Desa Pujon Kidul. Keunikan agen pembaharu yang juga sebagai pemegang otoritas kepala desa, memudahkan Udi untuk meyakinkan pemerintah desa karena sejatinya kepala desa itu sendirilah yang menginisiasi program ini.

Ketiga, deskripsi tokoh masyarakat. pertama, ditemukan bahwa Udi Hartoko adalah seorang tokoh masyarakat Desa Pujon Kidul yang juga berperan sebagai agen pembaharu. Alasannya adalah (a) Perlakuan masyarakat yang ketika bertemu dengan Udi, mereka menjawab sapaan dari Udi sembari menundukan kepalanya serta menggunakan bahasa jawa krama serta nada bicara yang sopan. Bahkan ketika dalam suatu diskusi terdapat pemuda yang kurang sopan dengannya dimana pemuda tersebut membentak Udi Hartoko karena

\footnotetext{
91 lbid., 78.

92 Rusdiana, "Optimalisasi peran BUMDes dalam Pengembangan Potensi Ekonomi Lokal sebagai Pilar Perekonomian Desa Pujon Kidul Kecamatan Pujon Kabupaten Malang," 69.

93 Hastiti, "Keterlibatan Karang Taruna Dalam Pemberdayaan Masyarakat Desa," 63.
} 
tidak sepakat dengan usulan Udi, ia langsung mendapat pembelaan dari masyarakat. ${ }^{94}$

(b) Udi menjadi tokoh masyarakat akibat ia menjabat sebagai kepala desa Pujon Kidul. ${ }^{95}$ Sebagai kepala desa ia memiliki hubungan sosial yang luas di dalam maupun di luar desa. Hubungan sosial yang luas di dalam desa ditunjukan dengan fakta bahwa setiap kali ia menyapa warga masyarakat, mereka selalu mengenali, tampak akrab, dan langsung merespon sapaan Udi. la juga menjadi pemimpin kegiatan masyawarah di balai pertemuan desa hingga memimpin peresmian program kafe sawah di depan warga desa Pujon Kidul. Sedangkan hubungan sosial ke luar desa ditunjukan dengan Udi yang mampu menjadi pihak yang menghubungkan antara warga desa dengan pemerintah di luar desa dalam hal pendirian program desa wisata Pujon Kidul. ${ }^{96}$

Peran ganda Udi sebagai agen pembaharu dan tokoh masyarakat mampu mempercepat penerimaan khususnya pada proses mengenalkan dan mempersuasikan inovasi. Alasannya, sebenarnya perubahan sikap penerimaan inovasi sudah terjelaskan sebelumnya bahwa hal tersebut akibat peran dari agen pembaharu. Namun uniknya, Udi adalah agen pembaharu yang dihormati oleh masyarakat selayaknya tokoh masyarakat. ${ }^{97}$ Artinya ketika menjadi agen pembaharu, secara psikologis ujaran dan

94 Semangat Pujon, video Youtube, 09:30-11:42, di unggah oleh "Cafe Sawah," 5 Juli 2018, https://www.youtube.com/watch?v=E3Vykl66yss\&t= 389s.

95 Perjuangann Udi Hartoko Membangun Desa Wisata Pujon Kidul, 00:55-00-58, Video Artikel Internet, diunggah oleh "Medcom", https://www.medcom.id/embed/MkMnRXvK. (diakes 7 Juni, 2020)

96 Semangat Pujon, video Youtube, 03:00-18:42, di unggah oleh "Cafe Sawah," 5 Juli 2018, perbuatannya mudah dipercaya oleh masyarakat akibat kemampuan opinion leader-nya. Efeknya, proses pengenalan dan persuasi oleh agen pembaharu bisa lebih cepat. Hal ini bisa mempercepat proses difusi, akibat aktor pemberdayanya berperan ganda sebagai agen pembaharu sekaligus juga tokoh masyarakat.

Respons penerimaan dibuktikan dengan perubahan pola pikir masyarakat yang sudah memahami program. Hal ini menyebabkan yang awalnya masyarakat ragu untuk berpartisipasi, sekarang malah mendorong anaknya setelah lulus SMP untuk berpartisipasi saja ke program kafe sawah. ${ }^{98}$

Kedua, ditemukan bahwa Amirul Muttaqin adalah seorang tokoh masyarakat. la adalah seorang ketua karang taruna desa Pujon Kidul. Hal ini ditandai ketika Udi hendak menyasar kalangan pemuda desa agar mau berpartisipasi, yang pertama kali ia ajak adalah Amirul Muttaqin sebagai orang yang di segani di kalangan pemuda. Hal ini berperan dalam mendorong pemuda lain untuk mau segera berpartisipasi karena langsung diajak oleh Amirul sebagai orang yang disegani di kalangan pemuda. ${ }^{99}$

Terdapat keunikan bahwa Udi Hartoko tidak hanya memenuhi karakter sebagai agen pembaharu saja, namun ia juga memenuhi karakter sebagai tokoh masyarakat.

https://www.youtube.com/watch?v=E3Vykl66yss\&t= 389s.

97 Semangat Pujon, video Youtube, 09:30-11:42, di unggah oleh "Cafe Sawah," 5 Juli 2018, https://www.youtube.com/watch?v=E3Vykl66yss\&t= 389s.

98 Hastiti, "Keterlibatan Karang Taruna Dalam Pemberdayaan Masyarakat Desa, 103.

99 Hastiti, "Keterlibatan Karang Taruna Dalam Pemberdayaan Masyarakat Desa," 93. 
Ditemukan juga Amirul Muttaqin sebagai tokoh masyarakat khususnya di kalangan para pemuda.

Keempat, adalah saluran komunikasi. Secara umum saluran komunikasi yang digunakan oleh Udi Hartoko dalam menyebarkan inovasi ini menggunakan saluran komunikasi interpersonal musyawarah. Berikut ulasan datanya. Pertama, melakukan pemetaan masalah dan potensi desa yang menggunakan dialog dengan masyarakat. Teknisnya adalah berdialog dengan warga mulai dari RT 1 hingga RT $18 .{ }^{100}$ Kedua, membuat strategi program berdasarkan pemetaan masalah dan potensi dalam acara musyawarah perencanaan pembangunan dan forum rencana pemerintah desa. ${ }^{101}$ Total forum yang dilakukan 20 kali dengan masyarakat dan 1 kali khusus dengan pemuda. 102 Ketiga, menyebarluaskan program yang telah dibuat dengan sosialisasi ke warga. ${ }^{103}$ Terakhir, berbagai evaluasi program dan penyelesaian masalah program dilakukan dengan saling berdikusi antar masyarakat. ${ }^{104}$ Maka dapat disimpulkan saluran komunikasi yang digunakan oleh Udi Hartoko secara umum adalah saluran komunikasi musyawarah.

Penggunaan saluran komunikasi musyawarah berperan menjadikan proses pengenalan dan persuasi lebih efisien. Alasannya adalah musyawarah ini sesuai dengan karakter komunikasi masyarakat

100 Damayanti, "Peran Bumdes Dalam Pengembangan Desa Wisata Pujon Kidul," 77-78.

101 A, Sunariyanto dan fiffudin, "Implementasi Kebijakan Dana Desa Untuk Pengembangan Potensi Desa," 34.

102 Ibid., 39

103 Nadiasari dan Nurhadi, "Pengorganisasian Kelompok Sadar Wisata Melalui Program Desa Wisata di Desa Pujon Kidul," 99.
Pujon Kidul yang tradisonal. Akibat mayoritas masyarakatnya adalah seorang petani dan peternak tradisional desa, maka tidak ada kebutuhan bagi mereka untuk berkomunikasi dengan perantara teknologi. Selain itu secara karakter pendidikan, ekonomi, dan norma sosial, masyarakat desa Pujon Kidul adalah masyarakat yang konservatif, ${ }^{105}$ sehingga budaya komunikasi yang muncul adalah komunikasi secara langsung, bukan diperantarai oleh teknologi yang cenderung berbiaya mahal dan lebih rumit jika dibandingkan dengan saluran komunikasi musyawarah.

Efeknya, proses pengenalan inovasi bisa lebih mudah. Karena untuk mengenal inovasi, masyarakat tidak perlu menyiapkan teknologi komuniasi apapun. Sebaliknya, mereka cukup datang ke tempat diadakannya musyawarah. Saluran ini juga memudahkan pada proses persuasi karena proses feedback bisa berjalan dengan cepat. Hal ini mampu menjadi aspek penunjang dalam mempermudah Udi dalam meyakinkan masyarakat serta langsung merespons saat itu juga ketika ada keraguan dan penolakan dari masyarakat ketika sedang bermusyawarah bersama.

Hal tersebut dibuktikan dengan data yang menyatakan bahwa komunikasi berjalan lancar antar stakeholder. Masyarakat mudah melakukan musyawarah yang diadakan oleh pemerintah, entah itu musyawarah desa

104 Muchamad Fahmi Arif, "Partisipasi Masyarakat Dalam Aktivitas Komunikasi Pemberdayaan Desa Wisata (Studi Pada Masyarakat Desa Wisata Pujon Kidul, Kecamatan Pujon, Kabupaten Malang)," (skripsi: Universitas Muhammadiyah Malang, 2019), 85.

105 Rusdiana, "Optimalisasi peran BUMDes dalam Pengembangan Potensi Ekonomi Lokal sebagai Pilar Perekonomian Desa Pujon Kidul Kecamatan Pujon Kabupaten Malang," 86-87. 
(Mudes) atau Musyawarah perencanaan pembangunan (Musrembang). ${ }^{106}$

Kelima, adalah deskripsi norma sistem. Secara umum karakter norma Desa Pujon Kidul adalah norma sistem tradisonal. Berikut adalah data penunjangnya: (a) Masyarakat Desa Pujon Kidul cenderung susah menerima perubahan. Susah untuk menanamkan hal-hal baru kepada mereka. Jadi diperlukan ketelatenan dalam hal ini; ${ }^{107}$ (b) Hal ini dipengaruhi oleh mayoritas masyarakat yang berpendidikan rendah. Spesifiknya 51\% masyarakat hanya tamatan sekolah dasar, $16 \%$ tidak pernah mengenyam pendidikan sama sekali, dan $11 \%$ masyarakat tidak tamat sekolah dasar. Artinya $77 \%$ masyarakatnya hanya berpendidikan SD ke bawah; 108 (c) Masyarakat Pujon Kidul masih memiliki ikatan kekerabatan yang cukup tinggi. Hal ini ditunjukan dengan adanya budaya gotong royong yang kuat. Dalam berpartisipasi tenaga fisik, semisal pembangunan beberapa fasilitas dan infrastruktur, masyarakat melakukannya secara gotong royong. ${ }^{109}$ Partisipasi secara gotong royong ini mampu memudahkan proses percontohan bagi masyarakat lain yang belum berpartisipasi.

(a) Tertutup dengan perubahan bisa menghambat proses difusi inovasi khususnya pada tahap persuasi. Alasannya

106 Khomzi, Handono dan Trianawati, "Sinergisitas Stakeholder Dalam Pengembangan Desa Wisata Pujon Kidul Kabupaten Malang," 28.

107 Rusdiana, "Optimalisasi peran BUMDes dalam Pengembangan Potensi Ekonomi Lokal sebagai Pilar Perekonomian Desa Pujon Kidul Kecamatan Pujon Kabupaten Malang," 87.

108 Admin, "sistem informasi elektronik," SIE Pujon Kidul, https://sie.pujonkidul.desa.id/penduduk.php. (diakses 7 juni 2020). adalah paradigma ini akan mempersulit masyarakat untuk percaya secara emosional dengan inovasi. Sehingga membutuhkan waktu lama untuk meyakinkan masyarakat. Hal ini ditandai dengan data yang menyatakan bahwa proses penyadaran agar lebih terbuka adalah proses terlama. ${ }^{110}$

(b) Berpendidikan rendah menjadi faktor dalam menghambat proses difusi inovasi, khususnya pada tahap pengenalan. Alasannya adalah kecenderungannya orang yang berpendidikan rendah tidak terbiasa berfikir konseptual ${ }^{111}$ dan program desa wisata Pujon Kidul adalah sebuah konsep yang hendak dikenalkan ke masyarakat. Sehingga proses pengenalan tidak bisa dilakukan satu dua kali. Namun harus ditekankan berulang kali. Data menyatakan bahwa masyarakat sulit membedakan konsep desa wisata dengan konsep wisata "Jatim Park" di kota Batu. Warga kerap kali menyamakan. Efeknya warga merasa pesimis karena dana desa tidak akan cukup untuk mendanainya. Padahal keduanya berbeda. ${ }^{112}$

(c) Kekerabatan yang memunculkan budaya gotong royong berperan memudahkan usaha percontohan untuk masyarakat lain yang belum mengenal tentang penerapan inovasi ini secara konkret. Hal ini bisa terjadi akibat partisipasinya dilakukan secara beramai-ramai. Kolektivitas dalam goyong

\footnotetext{
109 Damayanti, "Peran Bumdes Dalam Pengembangan Desa Wisata Pujon Kidul," 81.

110 Admin, "Tips Membangun Desa Wisata Ala Pujon Kidul", Desa Bisa, https://www.desabisa.com/tips membangun-desa-wisata-ala-pujon-kidul. (diakses 7 juni 2020).

111 Purwanto, "Tujuan Pendidikan Dan Hasil Belajar Domain Dan Taksonomi" Jurnal Teknodik Vol. 09, No. 16 (2015): 146.

112 Hastiti, "Keterlibatan Karang Taruna Dalam Pemberdayaan Masyarakat Desa, 122-123.
} 
royong juga memberikan kesan bahwa ada banyak warga yang sudah menerima inovasi. Sehingga mendorong yang selainnya untuk menerima inovasi juga. Budaya gotong royong masuk kedalam pembahasan karena norma sistem yang dibahas tidak hanya yang menghambat saja, namun juga yang mendukung. Terdapat keunikan bahwa norma tradisional yang umumnya dianggap menghambat namun dalam desa Pujon bisa mendukung proses difusi inovasi.

Bukti Bahwa gotong royong berperan mendukung adalah berdasarkan pernyataan Anas Taufiq, salah satu penggarak desa wisata Pujon Kidul. la menyatakan bahwa proses pembangunan infrastruktur pengadaan program seperti pembuatan toilet, pemasangan banner, hingga pembuatan rest area yang bisa berjalan lebih cepat karena ada banyak warga yang terdorong untuk berpartisipasi. ${ }^{113}$ Aktivitas pengembangan program desa wisata Pujon Kidul yang dilakukan secara gotong royong ini mampu menjadi objek percontohan bagi masyarakat yang selainnya. Sehingga secara tidak langsung mampu memudahkan proses difusi inovasi.

Keenam, adalah deskripsi penerapan prinsip homophily-heterophily. Secara umum Udi menerapkan prinsip homophily dalam proses difusi inovasi. Berikut adalah datadata penunjangnya: (a) Udi Hartoko dan pemuda karang taruna yang mendifusikan inovasi sama-sama berasal, tinggal, dan besar di Desa Pujon Kidul. Mereka adalah

113 Damayanti, “Peran Bumdes Dalam Pengembangan Desa Wisata Pujon Kidul,", 81.

114 Hastiti, "Keterlibatan Karang Taruna Dalam Pemberdayaan Masyarakat Desa, 64-76.

${ }^{115}$ Admin, "Tips Membangun Desa Wisata Ala Pujon Kidul", Desa Bisa, https://www.desabisa.com/tips- orang asli desa. ${ }^{114}$ (b) Kecenderungan mereka sama-sama suku Jawa, agama Islam, dan bahasa kesehariannya adalah bahasa Jawa. Begitu juga dalam hal agama, yaitu sama-sama beragama Islam karena sebelumnya dalam bab pendahuluan telah dinyatakan bahwa 99\% masyarakatnya homogen beragama Islam. (c) Kalau kesamaan sebelumnya terbangun secara natural, Namun kesamaan yang ini disengaja muncul ada. Udi membangun kesamaan visi dengan masyarakat desa. Visi tersebut adalah sama-sama bergerak untuk kesejahteraan desa. 115 Membangun kesamaan visi adalah keunikan karena dalam teori disebutkan bahwa prinsip homophily itu muncul secara natural, namun Udi mampu membuatnya secara mandiri.

Udi membangun banyak homophilius kepada masyarakat desa. Hal ini berperan membentuk hubungan saling percaya antara agen pembaharu dengan masyarakat. (a) Kesamaan dalam penggunaan bahasa. Akibat agen pembaharu dan masyarakat sama-sama berasal dari Desa Pujon Kidul, maka memudahkan proses komunikasi. Proses komunikasi akan berjalan lancar dengan memperkecil hambatan komunikasi karena kesamaan bahasa. Dalam data video di mana ketika Udi dan warga saling berdikusi, mereka sama-sama menggunakan bahasa Indonesia dicampur bahasa jawa dan komunikasi dari kedua belah pihak tetap bisa berjalan lancar. ${ }^{116}$

membangun-desa-wisata-ala-pujon-kidul. (Diakses 7 juni 2020).

116 Semangat Pujon, video Youtube, 08:45-14:10, di unggah oleh "Cafe Sawah," 5 Juli 2018, https://www.youtube.com/watch?v=E3Vykl66yss\&t= 389s. 
(b) Kesamaan asal usul antara agen pembaharu dengan masyarakat akan membentuk ikatan kepercayaan. Masyarakat akan lebih mudah percaya dengan inovasi karena inovasi ini diinisiasi oleh agen pembaharu yang berasal dari desa yang sama. Efeknya, memudahkan warga desa untuk percaya akibat adanya prinsip kesatuan komunitas masyarakat.

(c) Kesamaan visi yang dibentuk antara agen pembaharu dengan masyarakat di mana visinya adalah sama-sama bertujuan untuk membangun desa, bisa mendorong masyarakat untuk menerima inovasi. Kesamaan visi mampu mendorong masyarakat untuk bergabung dalam program desa wisata Pujon Kidul karena mereka akan berfikir bahwa menerima inovasi sama dengan menyelesaikan masalah masyarakat. Sehingga warga akan merasa diuntungkan apabila menerima inovasi.

\section{Kesimpulan}

Secara umum berbagai komponen sistem sosial tersebut memiliki peran yang beragam dalam memberikan peran positif terhadap proses difusi inovasi program desa wisata Pujon Kidul. Di antaranya adalah: (a) Pemuda karang taruna desa berperan menjadi objek percontohan kepada masyarakat pada masa awal pengenalan. (b) Udi Hartoko yang secara aktif berperan melakukan kegiatan pengenalan, persuasi, hingga berusaha untuk mempertahankan partisipasi masyarakat pada lingkup keputusan individu, kelompok masyarakat, hingga otoritas pemerintahan. (c) Udi Hartoko dan Amirul sebagai tokoh masyarakat berperan mempercepat usaha agen pembaharu dalam menjalankan berbagai perannya untuk mendifusikan inovasi. (d) Pemilihan saluran komunikasi musyawarah yang sesuai dengan karakter masyarakat desa menjadikan aktivitas transfer informasi efektif dan efisien antara agen pembaharu dengan masyarakat. (e) Budaya gotong royong pada norma sistem tradisional yang mempercepat aktivitas partisipasi dengan cara memudahkan proses percontohan aktivitas ke masyarakat desa. (f) Ada banyak kesamaan (homophilius) antara Udi Hartoko dengan masyarakat yang menunjang terbangunnya kepercayaan masyarakat terhadap inovasi.

Inilah yang menyebabkan inovasi program desa wisata Pujon Kidul berhasil diterima dan dijalankan oleh masyarakat desa, yaitu karena semua komponen sistem sosialnya disadari dan diperankan sedemikian rupa serta disesuaikan dengan konteks desa Pujon Kidul. Hingga akhirnya komponen sistem sosial tersebut mampu berperan positif dalam proses difusi inovasi.

Berdasarkan temuan studi di atas, saran untuk para peneliti selanjutnya, bisa melakukan studi lebih lanjut dengan meneliti komponen sistem sosial satu per satu. Dengan begitu temuan bisa lebih spesifik dan beragam.

Studi tentang komponen sistem sosial dalam proses difusi inovasi ini memiliki manfaat bagi para pembaca, khususnya untuk kalangan yang bekerja sebagai pekerja sosial atau lembaga dakwah yang hendak melakukan dakwah dengan jalan memberdayakan masyarakat islam. Oleh karenanya artikel ini bisa menjadi contoh nyata dinamika penerapan teori komponen sistem sosial dalam proses difusi inovasi. Sehingga pembaca bisa mengambil pembelajaran dari penerapan komponen 
sistem sosial dalam proses difusi inovasi program desa wisata Pujon Kidul, mampu mempelajari prinsip dalam mempertimbangkan peran komponen sistem sosial dan bisa mengaplikasikannya di masing-masing konteks di desa wisata lainnya.

\section{Bibliografi}

A, Luvia Intan S., Sunariyanto dan Fiffudin. "Implementasi Kebijakan Dana Desa Untuk Pengembangan Potensi Desa (Studi Kasus di Desa Pujon Kidul Kecamatan Pujon Kabupaten Malang)." JE_Mild Vol. $10 \quad$ No. 2 (2019). http://riset.unisma.ac.id/index.php/MILD/article/view/4493.

Admin

"Sistem

Informasi

Elektronik,"

https://www.sie.pujonkidul.desa.id/baca_berita.php?judul=Pembicara\%20di\%20Annual \%20International\%20Forum\%20an\%20Economic\%20Develobment\%20ang\%20Public\%2 Opolice\%20(AIFED). (diakses tanggal 13 Juni, 2020).

Admin. "Tips Membangun Desa Wisata Ala Pujon Kidul," desa bisa, https://www.desabisa.com/tips-membangun-desa-wisata-ala-pujon-kidul. (diakses tanggal 7 Juni, 2020)

Aesyah, Siti. Masa Puber Saat Remaja. Semarang: Mutiara Aksara, 2019.

Asyar, Doni. "Ini Rahasia Pak Kades Udi Hartoko Kembangkan Desa Wisata Pujon Kidul Malang," Radio Idola, https://www.radioidola.com/2017/ini-rahasia-pak-kades-udi-kembangkandesa-wisata-pujon-kidul-malang. (diakses tanggal 7 Juni, 2020).

Basri, Muhammad Luqman. "Kegagalan Program Pemberdayaan Masyarakat Ditinjau Dari Proses Inovasi (Studi Kasus Pada Program Budidaya Lele Desa Kucur Kecamatan Dau Kabupaten Malang)." Disertasi Program Pascasarjana Universitas Negeri Malang, 2015.

Damayanti, Citra Tirtaningtyas, "Peran Bumdes Dalam Pengembangan Desa Wisata Pujon Kidul," Skripsi Program Studi Sosiologi, Universitas Muhammadiyah Malang, 2019.

Departemen Agama RI. Al-Qur'an Tajwid dan Terjemah. Jakarta: Dharma Art. 2015.

E, Figueroa M., \& Kincaid D.L. (2010). Social, Cultural and Behavioral Correlates of Household Water Treatment and Storage. Center Publication HCl 2010-1: Health Communication Insights, Baltimore: Johns Hopkins Bloomberg School of Public Health, Center for Communication Programs. http://ccp.jhu.edu/documents/Household\%20Water\%20Treatment\%20and\%20Storage \%202010.pdf.

Hastiti, Raisha. "Keterlibatan Karang Taruna Dalam Pemberdayaan Masyarakat Desa (Studi di Desa Pujon Kidul Kabupaten Malang Melalui Wisata Cafe Sawah)." Skripsi Program Studi Sosiologi, Universitas Muhammadiyah Malang, 2018.

Hidayati, Nur, "E-Government Dalam Pelayanan Pubik (Studi Kasus Tentang Faktor-Faktor Penghambat Inovasi Layanan E-Samsat Jatim di Kabupaten Gresik)." Skripsi Program Studi IImu Administrasi Negara Universitas Airlangga, 2016.

Hidayatullah, Wildan Arif. "Pemberdayaan Ekonomi Masyarakat Desa Dalam Memenuhi Aspek Maqashid Syariah Melalui Pendekatan Asset Based Community Development (Studi Pada Desa Wisata Pujon Kidul Kabupaten Malang Jawa Timur)," Tesis Program Studi Magister Ekonomi Syariah, Universitas Islam Negeri Maulana Malik Ibrahim, 2019. 
Imawan, Amrizal, Gugus Irianto, Yeney Widya Prihatiningsih. "Peran Akuntabilitas Pemerintah Desa Dalam Membangun Kepercayaan Publik." Jurnal Akuntansi Multiparadigma Vol. 10, No. 1 (2019). http://dx.doi.org/10.18202/jamal.2019.04.10009.

Ira, Widyarini S. dan Muhamad. "Partisipasi Masyarakat pada Penerapan Pembangunan Pariwisata Berkelanjutan." jurnal pariwisata terapan Vol. 3 No. 2 (2019). https://doi.org/10.22146/jpt.43802.

Khomzi, Ika Rizkyah, Setiyo Yuli Handono dan Anis Trianawati. "Sinergisitas Stakeholder Dalam Pengembangan Desa Wisata Pujon Kidul Kabupaten Malang." Jurnal Agribisnis Vol. 13 No. 2 (2019). https://doi.org/10.15408/aj.v13i2.13948.

Nadiasari dan Nurhadi. "Pengorganisasian Kelompok Sadar Wisata Melalui Program Desa Wisata di Desa Pujon Kidul." Jurnal Pendidikan Nonformal Vol. 14 No. 2 (2019). http://dx.doi.org/10.17977/um041v14i2p94-107.

Nasrullah Jamaluddin, Adon. Sosiologi Perdesaan. Bandung: Pustaka Setia, 2015.

Prabowo, Septiofera Eresus, Djamur Hamid, Arik Prasetya. "Analisis partisipasi masyarakat dalam pengembangan desa wisata (studi kasus pujon kidul kecamatan pujon kabupaten malang)." jurnal administrasi bisnis Vol. 33, No. 2 (2016). http://administrasibisnis.studentjournal.ub.ac.id/index.php/jab/article/view/1296/1630

Pramono, Zwenli. Membangun Desa Wisata Untuk Meningkatkan Ekonomi Kerakyatan. Yogyakarta: Rubrik, 2019.

Purwanto. "Tujuan Pendidikan Dan Hasil Belajar Domain Dan Taksonomi" Jurnal Teknodik Vol. 09, No. 16 (2015). http://dx.doi.org/10.32550/teknodik.v0i0.541

Rogers, Everett M. Diffusion Of Innovation. New York: Free Press, 2003.

Rusdiana, Qori. "Optimalisasi peran BUMDes dalam Pengembangan Potensi Ekonomi Lokal sebagai Pilar Perekonomian Desa Pujon Kidul Kecamatan Pujon Kabupaten Malang." Skripsi Program Studi Ekonomi Syariah, IAIN Tulungagung, 2019.

Soejatmiko. "Pujon Kidul Terima Award Sebagai Desa Wisata Agro Terbaik dari Kemendesa," Jawa Pos, 13 Mei, 2017. https://www.jawapos.com/wisata-dankuliner/travelling/13/05/2017/pujon-kidul-terima-award-sebagai-desa-wisata-agroterbaik-dari-kemendesa. (diakses tanggal 28 September, 2020).

Syafii, Imam. "Kelompok sadar wisata capung alas kabupaten malang raih penghargaan dari menteri pariwisata," jatim times, 28 September, 2017. https://jatimtimes.com/baca/159230/20170928/204403/kelompok-sadar-wisatacapung-alas-kabupaten-malang-raih-penghargaan-dari-menteri-pariwisata. (diakses tanggal 28 September, 2020).

Triaryanti, Intan Margaretha. "Collaborative Governance Dalam Pengelolaan Bumdes Di Desa Wisata Pujon Kidul, Kecamatan Pujon, Kabupaten Malang." Skripsi Program Studi Ilmu Administrasi negara, Universitas Airlangga, 2019. 